Dept. of Anatomy and Histology,

Faculty of Veterinary Medecine, Assiut University.

\title{
HISTOMORPHOLOGICAL CHANGES IN THE TESTES OF OREOCHROMIS NILOTICUS DURING BREEDING AND NON BREEDING SEASONS
}

(With 4 Tables and 10 Figures)

By

ENAS A.A. EL HAFEZ; DOAA M.M. MAHMOUD

SH.M. AHMED* and A.H.S. HASSAN

*Dept of Fish Diseases, Fac. of Vet. Med., Assiut University

التغيرات الهستومورفولوجية لخصي البلطي النيلي أثناء موسم التكاثر وموسم عدم التكاثر

إيناس أحد عبل الحافظ ، دعاء محمد مختار محمول ، شعبان محمد /حد ،

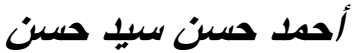

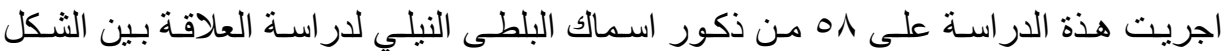

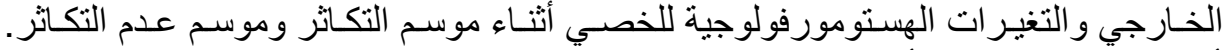

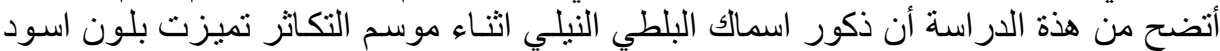

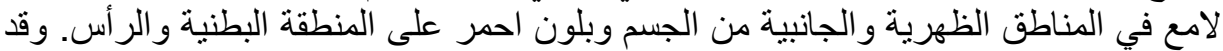

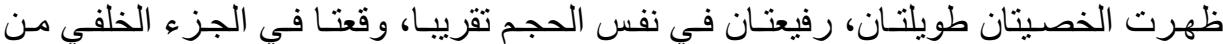

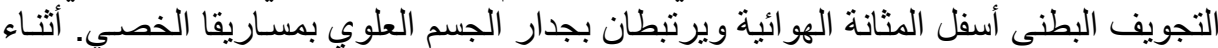

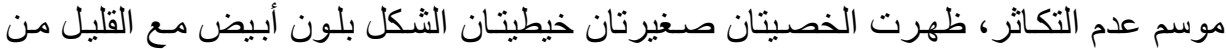

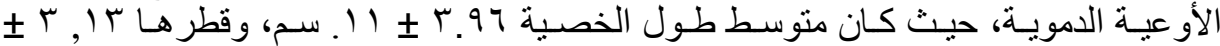

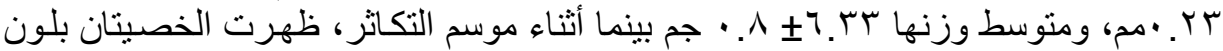

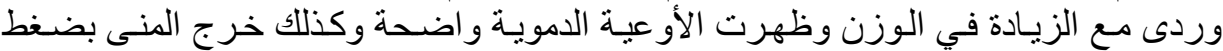

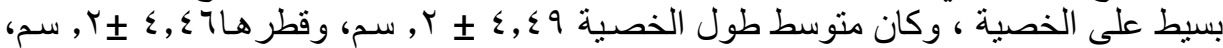

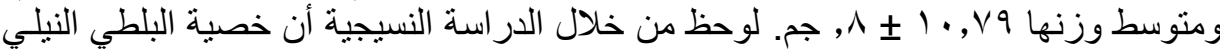

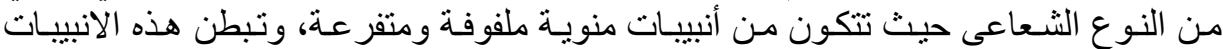

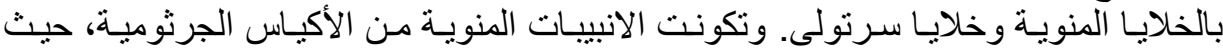

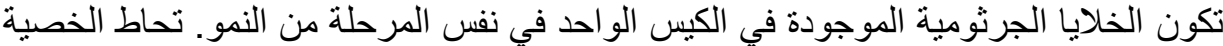

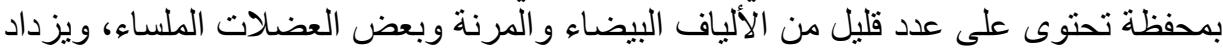

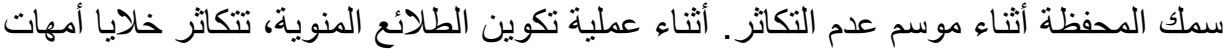

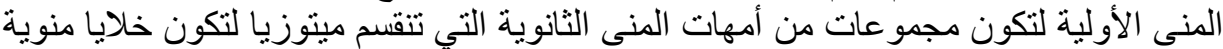

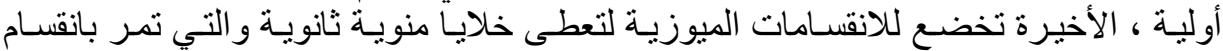

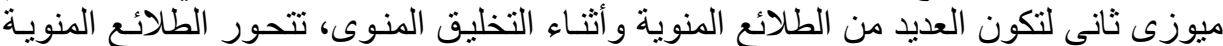

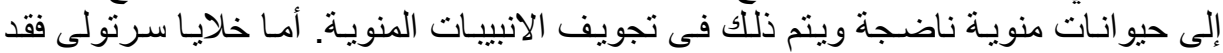


ظهرت بشكل كمثرى تحنوى على سيتو بلازم باهت ونواة قاعدية، حيث تكونت جدر الأكياس

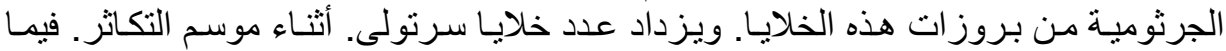

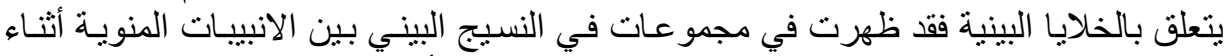

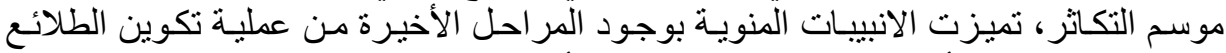

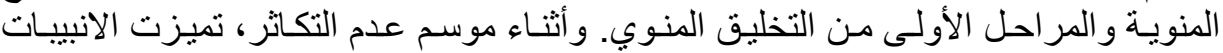

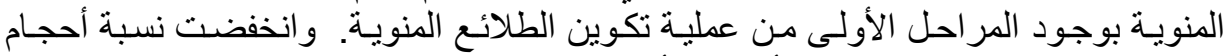
الانبيبات المنوية بينماز زادت نسبة أحجام الأنسجة البينية.

\section{SUMMARY}

The present work was conducted to highlight the relationship between the external morphology of $O$. niloticus and the histomorphological changes of the testes during the breeding and the non breeding seasons. A total of 58 male fishes of $O$. niloticus were used in this investigation. The males showed bright black coloration on the dorsal and lateral parts of their body and red colour on the ventral part of their body and head during the breeding season. Testes were paired long narrow structure of approximate equal size, locating in the posterior body cavity, attached to the dorsal body wall by mesorchium. During the non-breeding season, the testes were small, thread- like and dull white in colour. During the breeding season, testes were pinkish in colour and increased in weight. The testis was covered with a capsule consisting of few collagenous, elastic fibers. Testicular parenchyma consisted of branched seminiferous tubules and interstitial tissue. The seminiferous tubules were lined with spermatogenic and Sertoli cells. Seminiferous tubules were made up of spermatocysts. During spermatogenesis, primary spermatogonia proliferated to form secondary spermatogonia which divided mitotically to form primary spermatocytes. The later underwent meiotic divisions to form secondary spermatocytes that passed with second meiotic divisions giving many spermatids which transformed into spermatozoa in the lumen of the seminiferous tubules. Sertoli cells were pyriform cells with slightly eosinophilic cytoplasm and one basal nucleus. During the nonbreeding seasons, the diameter of the seminiferous tubules reached $102.94 \pm 1 . .83 \mu \mathrm{m}$ and the mean number of Sertoli cells was $1.79 \pm 0.16$ /spermatocyst. During the breeding season, the diameter of the seminiferous tubules was $124.78 \pm 2.32 \mu \mathrm{m}$ and the mean number of Sertoli cells was $3.01 \pm 0.14 /$ spermatocyst.

Key words: O. niloticus, testes, breeding 


\section{INTRODUCTION}

Nile tilapia belongs to genus Oreochromis. This species is naturally distributed in Palestine, the Nile River as well as most parts of African Rivers \& lakes (Trewawas, 1982 and Beamish; Booth and Deacon, 2005). O. niloticus is gonochoristic, which each individual possessing a single sexual phenotype. Nile tilapia is characterized by extended spawning seasons, maturity at small size and a fast growth rate. It has been termed the aquatic chicken for its extraordinary production capabilities (Peterson; Slack; Brown- Peterson and McDonald, 2004). Tilapia have one pair of bilateral gonads locating in the posterior part of the body cavity immediately ventral to the swim bladder and attached by mesentries to the parietal peritoneum. Short ducts extend from the posterior end of the gonads to the genital pore. In addition to production of gametes, the gonads also produce hormones from endocrine tissue (Bond, 1979).

The aim of the present investigation is to highlight the relationship between the external morphology of the fish and the histomorphological changes of the gonadal tissue during different seasons of the year. Also, to detect the relationship between some environmental conditions such as water temperature and spawning activity.

\section{MATERIALS and METHODS}

The materials employed in this study consisted of randomly obtained 58 male adult specimens Oreochromis niloticus. The materials were collected every month from the Nile River at Elkhazan bridge in Assuit city during the year. The specimens ranging from $14.46 \pm 0.22$ $\& 13.92 \pm 0.16 \mathrm{~cm}$ in standard length and from $96.39 \pm 2.19 \mathrm{~g}$. in body weight. After recording the above mentioned measurements, the fish were dissected as soon as possible to obtain the testes.

Ttesticular measurements: The testes length $(\mathrm{cm})$ was measured individually (right\&left) using a ruler from the anterior to the posterior end. In addition their diameter $(\mathrm{mm})$ was measured individually (right\&left) using a caliber. Testes (right\&left) were also weighed individually using Berekel balance.

Gonadosomatic index (GSI): Monthly variation of gonadosomatic index provides good indication of the extent of development of gonad with respect to the time of year (Hatikakoty and Biswas, 2004). 
GSI was calculated monthly from each male fish (Table 1) using the following formula:

GSI \% = Gonads (testes) weight (g.) / Body weight (g.) x 100

A regular record of water temperature for every month was recorded for three times using water thermometer and the mean values were taken in order to study the possible correlation between the temperature and the spawning activity of $O$. niloticus (Table 2).

Histological preparation: The samples for histological examination were dissected as soon as possible from the anterior, middle and posterior parts of each testes $(1 \mathrm{x} 1 \mathrm{x} .05 \mathrm{~cm})$ and were immediately fixed in Bouin's fluid for 24 hours. The fixed materials were dehydrated in an ascending series of ethanol, cleared in methyl benzoate and then embedded in paraffin wax. Transverse and longitudinal paraffin sections at $5-8 \mu \mathrm{m}$ in thickness were cut and stained with the following histological stains; Harris haematoxylin and Eosin (Harri's, 1900), Grossmon's Trichrome (Grossmon, 1937), Periodic Acid -Schiff (PAS) (McManus, 1946), Verhoeff's stain (Verhoeff's, 1908).

Morphometrical measurements: By using Image analysis system (Leica Q500 MC) morphometric study applied on the representative stained sections, including: the thickness of tunica albuginea, diameter of seminiferous tubules. The volume percentage of seminiferous tubules and interstitial tssue. Number of Sertoli cells/ cross section of seminiferous tubules as well as per spermatocysts. The data was statistically analyzed by computer program SPSS ver II (Tables $3 \& 4$ ).

\section{RESULTS}

The present study showed that during breeding season, both upper \& lower jaws of sexually mature males were enlarged making their profile concave. Males exhibited bright gray color, as compared with those examined during non-breeding season. This bright color is lost as soon as this season is over .Breeding males had a distinct black lines appeared on the dorsal and lateral parts of their body, while red colour was found on the ventrolateral parts of their body and head (Fig. 1). These charactrestics are not appeared in non breeding males (Fig. 2).

Testes of male $O$. niloticus were paired long, narrow structure and approximate of equal size. They were located in the posterior part of the body cavity. During the non-breeding season, the testes were small, 
flaccid, thread- like and dull white in colour with slight vascularization (Fig. 3). During the breeding season, testes were soft, creamy in texture, turgid, pinkish in colour and increased in weight. The blood vessels were prominent and the milt run with slight pressure (Fig. 4). The mean testicular diameter of mature males used in present investigation during the breeding season was $4.46 \pm 0.20 \mathrm{~mm}$ and during the non- breeding season was $3.13 \pm 0.23 \mathrm{~mm}$. The histological investigation showed that the testis was bean- shaped in cross section and cylindrical in longitudinal section. Testis of tilapia was of the radial type, a system of seminiferous tubules passed from the dorsal and lateral wall of the testis to the central lumen (Fig. 5). The central lumen led to efferent ducts, which opened into the sperm duct or vas deferens that led to the urogenital pore (Fig. 6). The testis was enclosed completely by tunica albuginea, which was consisted of few collagenous fibers, some smooth muscle cells and elastic fibers. The testicular parenchyma was consisted of branching tubular seminiferous tubules \& interstitial tissue; a)- The seminiferous tubules; The seminiferous tubules was delimited by a basal lamina that showed PAS positive reaction and had a central lumen surrounded by the germinal epithelium which was made up of spermatogenic cells as well as Sertoli cells. The seminiferous tubules were made up of spermatocysts, that it formed by the cytoplasmic projections of Sertoli cells. The spermatocysts contained spermatogonia, primary spermatocytes, secondary spermatocytes and spermatids, while spermatozoa found in the lumen of the seminiferous tubule. Within each spermatocyst, the germ cells were at the same stage of development (Fig. 7).

\section{Spermatogenesis:}

The process of sperm formation occurred in spermatocysts and consisted of two distinct phases:

1 - Renewal, mitotic proliferation of spermatogonia.

2 - Meiosis followed by spermiogenesis.

The primary spermatogonia (sperm mother cells) were the largest cells of the germinative lineage, that could occur either isolated or in groups inside the cysts in the seminiferous tubules. They were large oval cells with very scarce, lightly basophilic cytoplasm and large round nucleus with a single nucleolus. Primary spermatogonia were found during the breeding and non-breeding seasons and were usually present within those seminiferous tubules locating peripherally under the tunica albuginea (Fig. 8). Primary spermatogonia proliferate to form clusters of secondary spermatogonia, which were rounded cells, smaller than 
primary spermatogonia. Each cluster was enclosed in a cyst and divided synchronously, mitotically to form primary spermatocytes that were smaller in size than secondary spermatogonia, the nucleus was strongly stained with heamatoxylin and the cytoplasm had little affinity for dyes. Meiotic divisions of primary spermatocytes produced secondary spermatocytes that were somewhat smaller than primary spermatocytes with weakly stained nucleus Second meiotic division produced haploid spermatids, those were small with scant cytoplasm, strongly basophilic nucleus. Spermatids inside the cyst increased in number towards the center of the testis. Metamorphosis of spermatids to spermatozoa occurred in the lumen of the testis tubules after the cyst had burst and this process is called spermiogenesis.

Spermatozoa were smaller than spermatids with strongly basophilic nucleus. They were found in the interior of the seminiferous tubules (Figs. 7), efferent ducts and sperm duct. Sertoli cells: Pyriform cells with slightly eosinophilic cytoplasm and one basal clear nucleus had an irregular contour with one clear nucleolus. Their adluminar surface was thrown into finger- like projections, whereas their basal surface was thrown into a complex system of stubby projections (Fig. 9). Their projections formed the borders of spermatocysts. Spermatogonia and spermatocytes did not touch the basal lamina, they were surrounded and enclosed by cytoplasmic expansions of Sertoli cells. Spermatids and earlier stages of spermatogenesis were associated with Sertoli cells (Fig. 10). b)- Interstitial tissue: The interstitial tissues occured between the seminiferous tubules, contained interstitial cells, fibroblasts, blood vessels and some collagenous fibers. The mean volume percentage of interstitial tissue during the non-breeding season was $30.8 \pm 1.72 \%$, while during the breeding season was $21.54 \pm 0.81 \%$. Interstitial cells (Leydig cells): Occupied greater part of the testis interstitum. They were formed of small or large clusters of polygonal cells containing an ovoid nucleus. These cells were located in the fibrous supporting connective tissue between seminiferous tubules (Fig. 10). During the non breeding season the tunica albugeia was thick and contained large amount of elastic fibers and smooth muscle fibers. The volume percentage of seminiferous tubules was reduced, and its mean value reached $70.19 \pm$ $1.0 \%$. The minimum mean value was $68.23 \pm 0.87 \%$ in February (Table 3). The diameter of the seminiferous tubules reduced, and its mean diameter reached $102.94 \pm 1.83 \mu \mathrm{m}$. The minimum mean value was $96.85 \pm 0.87 \mu \mathrm{m}$ in February. Seminiferous tubules were dominated by early stages of spermatogenesis (spermatogonia and primary 
spermatocytes) and had a narrow lumen with considerably fewer spermatocysts. In addition during the non-breeding season, the mean number of Sertoli cells was $6.4 \pm 0.5 /$ cross section of seminiferous tubules and $1.79 \pm 0.16 /$ spermatocyst. The minimum number was $5 \pm 0.31 /$ cross section of seminiferous tubules in February and $1.33 \pm 0.21 /$ spermatocyst in February (Table 4). The volume percentage of interstitial tissue increased during the non-breeding season, and its mean value reached $29.8 \pm 1.72 \%$. The maximum value was $36.77 \pm 1.0 \%$ in February (Table 3 ). During the breeding season the tunica albuginea was thin during the breeding season its mean thickness reached $7.10 \pm 0.36 \mu \mathrm{m}$ and the minimum mean value was $6.35 \pm 0.69$ $\mu \mathrm{m}$ in April. The volume percentage of seminiferous tubules increased, and its mean value reached $78.43 \pm 0.81 \%$. The maximum mean value was $80.11 \pm 0.96 \%$ in June. The diameter of the seminiferous tubules was significantly increased during the breeding season, and its mean diameter reached $124.78 \pm 2.32 \mu \mathrm{m}$. The maximum mean value was $141.51 \pm 1.21 \mu \mathrm{m}$ in July (Table 3 ). The seminiferous tubules widened and elongated toward the center of the testis where their lumen showed abundant sperms. The sperms were free and were almost neither linked nor bound to Sertoli cells. The seminiferous tubules were dominated by later stages of spermatogenesis (secondary spermatocytes and spermatids) and early stage of spermiogenesis (spermatids). Seminiferous tubules were strongly packed with spermatozoa in prospawning and spawning periods. During the breeding season, there was a significant increase in the number of Sertoli cells, its mean number reached $10.6 \pm 0.67 /$ cross section of seminiferous tubules and $3.01 \pm 0.14$ / spermatocyst. The maximum mean number was $13 \pm 1.37$ /cross section of seminiferous tubules in May and $3.5 \pm 0.42$ / spermatocyst in June (Table 4). The volume percentage of interstitial tissue decreased during the breeding season, and its mean value reached $21.54 \pm 0.81 \%$ (Table 4).

\section{Gonadosomatic index:}

GSI= gonads weight $\backslash$ body weight $\times 100$

GSI can be used as indicator for gonadal development. When gonadosomatic index reach a maximum value, this gives a perfect indication to the time of spawning.

Gonadosomatic indix were highest between May to July. GSI peaked in July (Table 1). The mean GSI during the breeding season was $11.15 \pm 0.39 \%$ While the mean GSI during the non- breeding season was $7.91 \pm 0.39 \%$ (Table 1 ). From the present investigation, the water 
temperatures were highly correlated with GSI and the optimum temperature for spawning was between $21^{\circ} \mathrm{C}$ to $24^{\circ} \mathrm{C}$ (from May to July) that was the peak period for the GSI (Table 2).

Table 1: Average monthly fluctuations in GSI.

\begin{tabular}{|l|c|c|c|c|}
\hline & $\begin{array}{c}\text { Number } \\
\text { of } \\
\text { specimens }\end{array}$ & $\begin{array}{c}\text { Mean body } \\
\text { weight (gm) }\end{array}$ & $\begin{array}{c}\text { Mean testis } \\
\text { weight (gm) }\end{array}$ & GSI \\
\hline Non-breeding season & 5 & 97.2 & 8.3 & 8.53 \\
\hline October & 5 & 95.0 & 7.6 & 8.0 \\
November & 5 & 90.0 & 6.6 & 7.33 \\
December & 5 & 82.4 & 6.0 & 7.28 \\
January & 5 & 83.2 & 5.9 & 7.09 \\
February & 4 & 96.25 & 8.9 & 9.24 \\
March & -------- & ------ & 7.0 & 7.91 \\
M+SE & 5 & 106.2 & 11.2 & -------- \\
breeding season & 5 & 103.2 & 11.4 & 11.04 \\
April & 5 & 104.2 & 12.7 & 12.18 \\
May & 5 & 103.0 & 12.8 & 12.42 \\
June & 4 & 100.75 & 10.75 & 10.66 \\
July & 5 & 99.1 & 10.1 & 10.1 \\
August & & & 11.77 & 11.5 \\
September & $5 \pm 2 E$ & & &
\end{tabular}

Table 2: The mean values of water temperature during different months of the year.

\begin{tabular}{|c|c|}
\hline Month & Temperature \\
\hline October & $18^{\circ} \mathrm{C}$ \\
\hline November & $16^{\circ} \mathrm{C}$ \\
\hline December & $11^{\circ} \mathrm{C}$ \\
\hline January & $11^{\circ} \mathrm{C}$ \\
\hline February & $13^{\circ} \mathrm{C}$ \\
\hline March & $15^{\circ} \mathrm{C}$ \\
\hline April & $19{ }^{\circ} \mathrm{C}$ \\
\hline May & $21^{\circ} \mathrm{C}$ \\
\hline June & $22^{\circ} \mathrm{C}$ \\
\hline July & $24^{\circ} \mathrm{C}$ \\
\hline August & $25^{\circ} \mathrm{C}$ \\
\hline September & $26^{\circ} \mathrm{C}$ \\
\hline
\end{tabular}


Table 3: The mean volume percentage of seminiferous tubules, interstitial tissue and diameter of seminiferous tubules $(\mu \mathrm{m})$ during different months of year.

\begin{tabular}{|c|c|c|c|}
\hline Months & $\begin{array}{l}\text { Volume percentage } \\
\text { of seminiferous } \\
\text { tubules }(\%)\end{array}$ & $\begin{array}{l}\text { Volume percentage } \\
\text { of interstitial tissue } \\
(\%)\end{array}$ & $\begin{array}{c}\text { Diameter of the } \\
\text { seminiferous } \\
\text { tubules }(\mu \mathrm{m})\end{array}$ \\
\hline $\begin{array}{c}\text { Non-breeding } \\
\text { season } \\
\text { October }\end{array}$ & $69.3 \pm 0.97$ & $30.8 \pm 0.88$ & $106.28 \pm 1.66$ \\
\hline November & $69.36 \pm 1.78$ & $30.64 \pm 1.88$ & $101.26 \pm 2.0$ \\
\hline December & $70.27 \pm 0.99$ & $29.73 \pm 0.97$ & $102.37 \pm 1.85$ \\
\hline January & $69.12+1.08$ & $30.88 \pm 2.76$ & $99.21 \pm 1.11$ \\
\hline February & $68.23 \pm 0.87$ & $36.77 \pm 1.00$ & $96.85 \pm 0.87$ \\
\hline March & $74.00 \pm 2.00$ & $26.00 \pm 0.96$ & $109.0 \pm 0.95$ \\
\hline $\mathrm{M} \pm \mathrm{SE}$ & $70.19 \pm 1.0$ & $29.8 \pm 1.72$ & $102.94 \pm 1.83$ \\
\hline $\begin{array}{c}\text { Breeding season } \\
\text { April }\end{array}$ & $78.75 \pm 1.23$ & $21.25 \pm 1.44$ & $112.1 \pm 0.93$ \\
\hline May & $79.11 \pm 0.87$ & $20.78 \pm 2.38$ & $119.52 \pm 1.24$ \\
\hline June & $80.11 \pm 0.96$ & $19.89 \pm 0.64$ & $132.11+1.98$ \\
\hline July & $78.88 \pm 1.09$ & $21.12 \pm 1.04$ & $141.51 \pm 1.21$ \\
\hline August & $76.33 \pm 0.95$ & $24.67 \pm 1.55$ & $125.0 \pm 1.22$ \\
\hline September & $76.0 \pm 0.78$ & $24.0 \pm 0.88$ & $118.44 \pm 0.83$ \\
\hline $\mathrm{M} \pm \mathrm{SE}$ & $78.43 \pm 0.81$ & $21.54+0.81$ & $\begin{array}{c}124.78 \pm 2.32 \\
*\end{array}$ \\
\hline
\end{tabular}

Values were represented by mean $\underline{ \pm}$ standard error (SE).

* means significant. 
Table 4: The mean thickness of the tunica albuginea, number of Sertoli cells / cross section of seminiferous tubules and / spermatocyst during different months of the year.

\begin{tabular}{|c|c|c|c|}
\hline Months & $\begin{array}{c}\text { Thickness of } \\
\text { tunica albuginea } \\
(\mu \mathrm{m})\end{array}$ & $\begin{array}{l}\text { Number of } \\
\text { Sertoli' cells/ } \\
\text { cross section }\end{array}$ & $\begin{array}{l}\text { Number of Sertoli' } \\
\text { cells/ spermatocyst }\end{array}$ \\
\hline $\begin{array}{c}\text { Non-breeding season } \\
\text { October }\end{array}$ & $14.35 \pm 0.36$ & $6.5 \pm 0.85$ & $1.8 \pm 0.66$ \\
\hline November & $10.98 \pm 0.78$ & $7 \pm 0.44$ & $1.83 \pm 0.3$ \\
\hline December & $14.02 \pm 0.75$ & $6 \pm 0.70$ & $1.83 \pm 0.16$ \\
\hline January & $14.38 \pm 0.88$ & $6 \pm 0.70$ & $1.66 \pm 0.33$ \\
\hline February & $16.70 \pm 1.76$ & $5 \pm 0.31$ & $1.33 \pm 0.21$ \\
\hline March & $15.58 \pm 1.86$ & $8 \pm 0.83$ & $2.33 \pm 0.49$ \\
\hline $\mathrm{M} \pm \mathrm{SE}$ & $14.33 \pm 0.96$ & $6.4 \pm 0.5$ & $1.79 \pm 0.16$ \\
\hline $\begin{array}{c}\text { Breeding season } \\
\text { April }\end{array}$ & $6.35 \pm 0.69$ & $9 \pm 1.30$ & $2.83 \pm 0.30$ \\
\hline May & $6.55 \pm 0.56$ & $13 \pm 1.37$ & $3.0 \pm 0.44$ \\
\hline June & $6.80+1.06$ & $10 \pm 0.70$ & $3.5 \pm 0.42$ \\
\hline July & $7.48 \pm 0.51$ & $11 \pm 0.44$ & $3.1 \pm 0.16$ \\
\hline August & $8.33 \pm 0.71$ & $10 \pm 0.70$ & $2.66 \pm 0.33$ \\
\hline Sebtember & $7.0 \pm 0.74$ & $10.5 \pm 0.33$ & $3.2 \pm 0.11$ \\
\hline $\mathrm{M} \pm \mathrm{SE}$ & $7.1 \pm 0.36$ & $\begin{array}{c}10.6 \pm 0.67 \\
\text { n.s. }\end{array}$ & $3.01 \pm 0.0 .14$ \\
\hline
\end{tabular}

Values were represented by mean \pm standard error (SE).

n.s. means not significant. $* *$ means highly significant. 

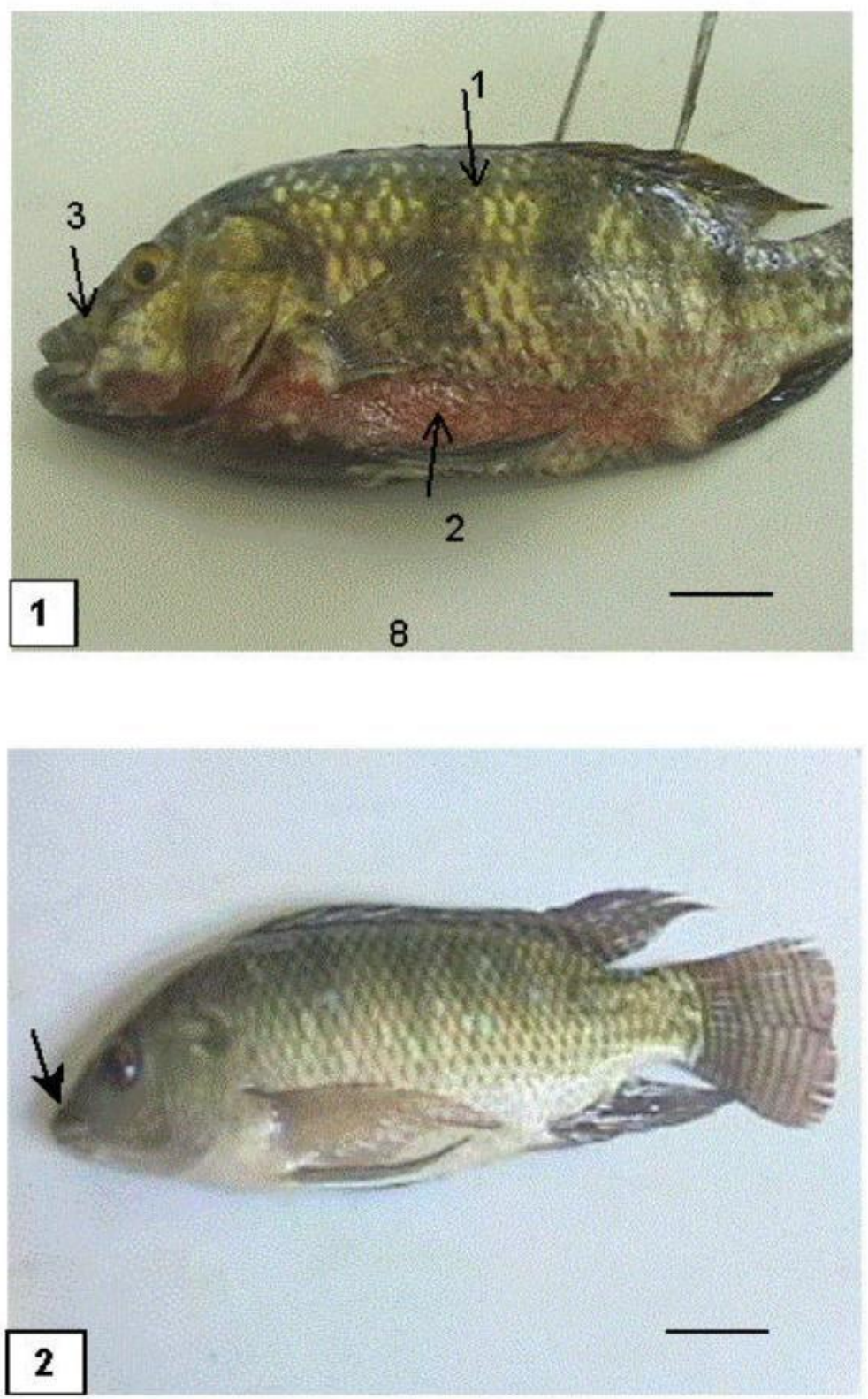
Assiut Vet. Med. J. Vol. 55 No. 121 April 2009

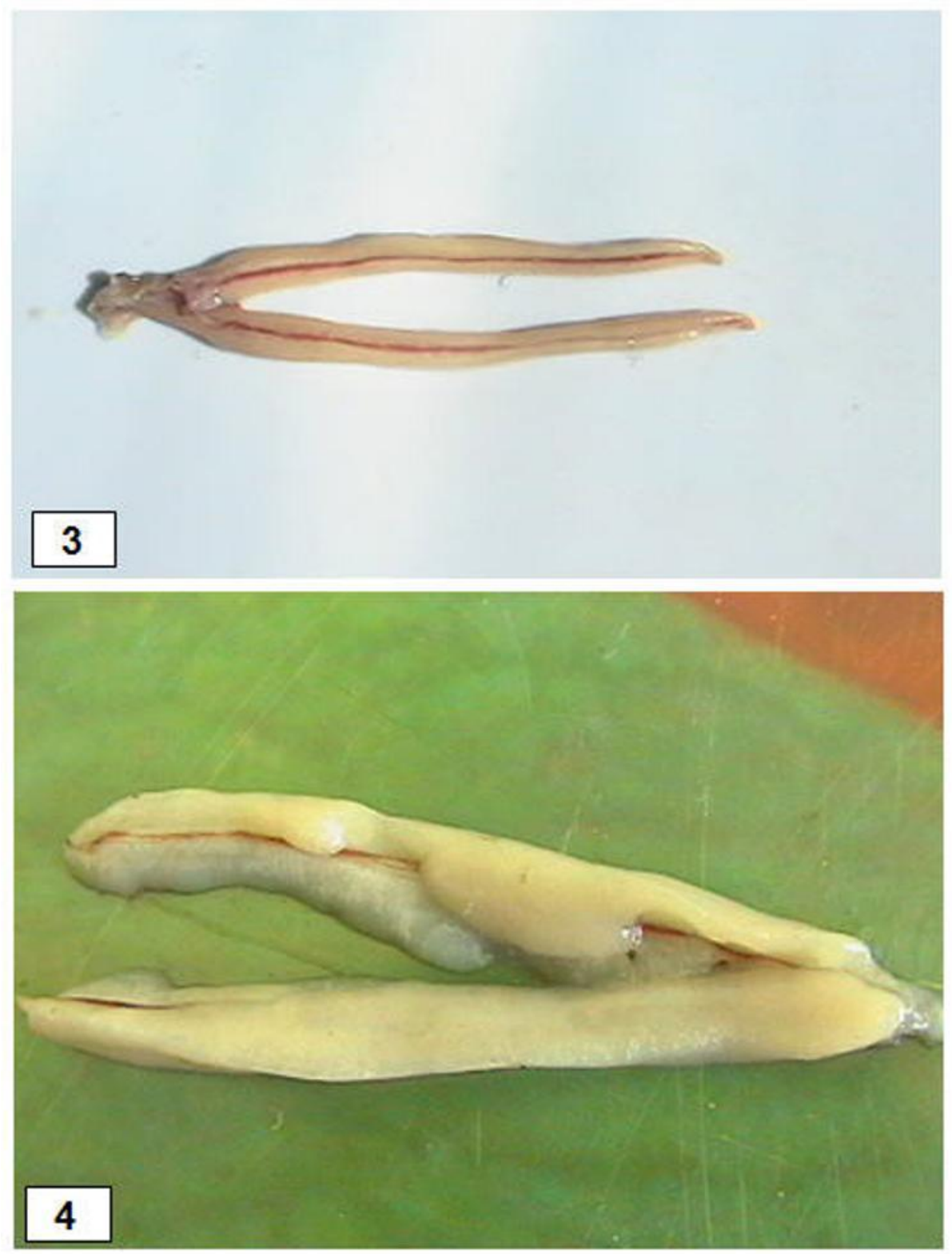


Assiut Vet. Med. J. Vol. 55 No. 121 April 2009
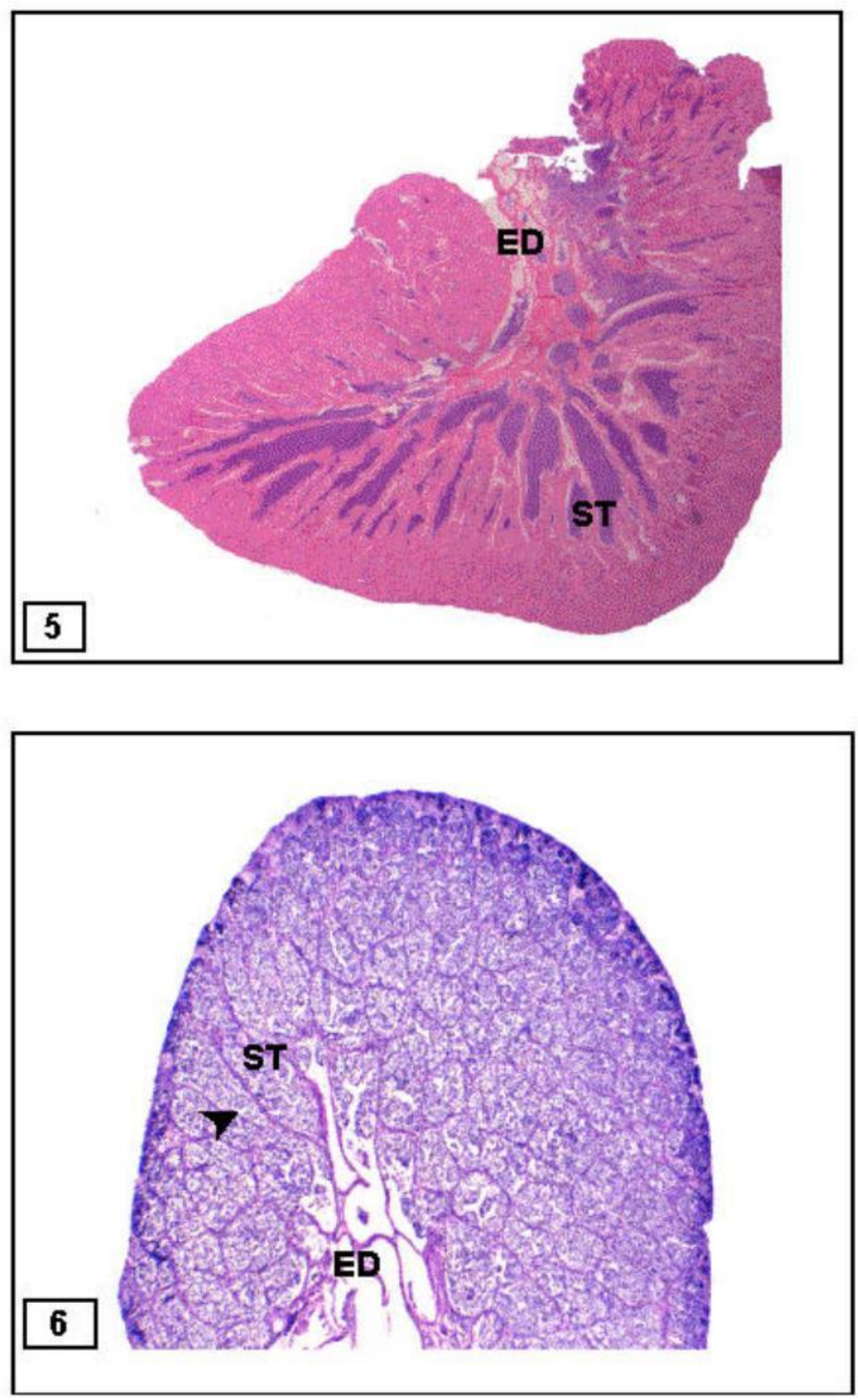

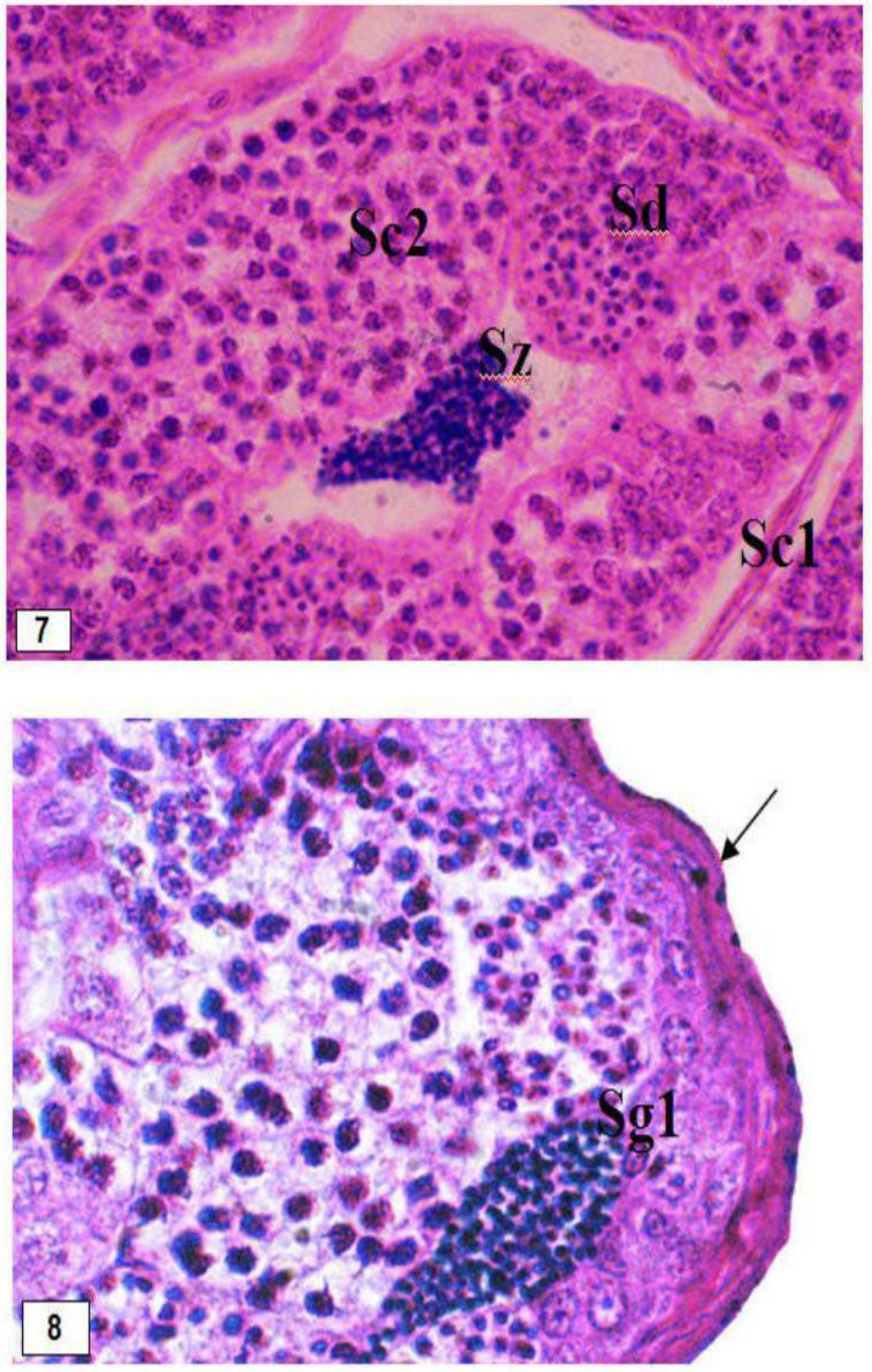

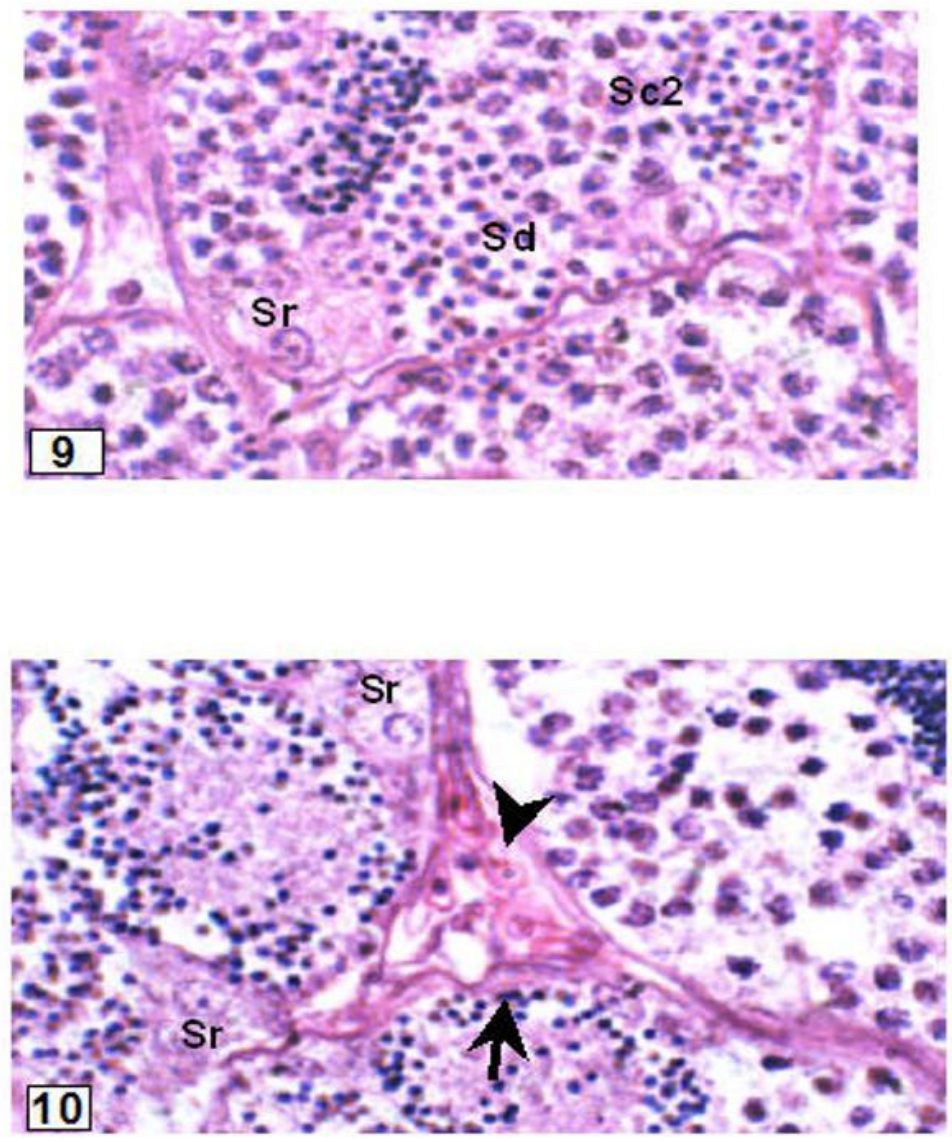

\section{LEGENDS}

Fig. 1: Lateral view of the male $O$. niloticus during the breeding season, showing a distinct bright black color on the dorsal and lateral areas of the body (arrow 1), red color on the ventrolateral parts of their body and head (arrow 2) and the jaws enlarged making their profile concave (arrow 3$)$. $(\mathrm{Bar}=0.85)$ 
Fig. 2: Lateral view of the male $O$. niloticus during the non-breeding season, showing the absence of the bright black and red color and the jaws reduced in size making their profile convex (arrow). $($ Bar $=0.85)$

Fig. 3: Photograph of the testes of O. niloticus during the non-breeding season. The testes were small dull white in color.

Fig. 4: Photograph of the testes of $O$. niloticus during the breeding season. The testes were large white in color.

Fig. 5: Cross section in the testis showing distended seminiferous tubules (ST) that opened in the center of the testis in the efferent ducts (ED).(Heamatoxylin and Eosin, X 10)

Fig. 6: Photomicrograph of the testis showing seminiferous tubules (ST) that opened in the center of the testis in the efferent ducts (ED).(Periodic acid Schiff reagent, X 50)

Fig. 7: Photomicrograph in the testis during the breeding season showing seminiferous tubule contained primary spermatocytes (Sc1), secondary spermatocytes (Sc2), spermatids (Sd) and spermatozoa (Sz). (Heamatoxylin and Eosin, X 400)

Fig. 8: Photomicrograph in the testis showing the thick tunica albuginea (arrow). Notice the presence of primary spermatogonia ( $\mathrm{Sg} 1)$ under the tunica albuginea. (Heamatoxylin and Eosin, X 400

Fig. 9: Photomicrograph in the testis showing seminiferous tubule contained secondary spermatocytes ( $\mathrm{Sc} 2)$, spermatid $(\mathrm{Sd})$ and Sertoli cells (Sr). (Heamatoxylin and Eosin, X 400)

Fig. 10: Photomicrograph in the testis showing interstitial tissue (arrow) contained interstitial cells (arrow head). Notice the presence of Sertoli cells (Sr). (Heamatoxylin and Eosin, X 1000)

\section{DISCUSSION}

The present work was carried out on 58 specimens of male $O$. niloticus throughout the year, in order to observe the morphological and histological changes in the testes during different seasons of the year. The result showed that the breeding season for reproduction was between April and September, while non-breeding season was between October and March, the current findings simulate those of Caputo, V.; Mesa, M.L.; Candi, G. and Cerioni, P.N. (2003) and Cinquetti and Dramis (2003). The testicular morphology observed in the present study is similar to that described in the catfish Arockiaraj, A.J.; Haniffa, M.A.; Seetharaman, S. and Singh, S. (2004) and Oreochromis mossambicus 
(Hatikakoty and Biswas, 2004). As testes develop, they present accentuated differences in size and form. The mature stage was well evidenced by its largest volume corresponding to increasing size of the seminiferous tubules and quantity of spermatozoa. Variation in the form occured from the thread- like appearance during the non-breeding season and becoming large and cylindrical during the breeding season, and resulting wrinkled after spawning. The present investigation revealed that the testes were covered by the tunica albuginea that formed of collagenous and elastic fibers, fibroblasts and smooth muscle fibers. The tunica albuginea was thin during the breeding season as a result of progressive expansion of the testis by maturation, its mean thickness reached $7.10 \pm 0.36 \mu \mathrm{m}$. while during the non-breeding season, its mean thickness reached $14.33 \pm 0.96 \mu \mathrm{m}$. The elastic fibers that found in the wall and especially visible after spawning are responsible for contraction of the testis and discharge of sperms, similar observation was reported by (Arockiaraj, et al., 2004). The current observations revealed the presence of large amounts of spermatozoa in the lumen of the distended seminiferous tubules and in the sperm ducts leading to increase in weight of the testes to reach its maximum weight during the breeding season $(11.77 \pm 0.41 \mathrm{gm})$. On the other hand, the testes during the nonbreeding season appeared flaccid and dull white in coloure and its mean weight was $7.0 \pm 0.56 \mathrm{gm}$. Testis of tilapia is of radial type where seminiferous tubules arranged radially from testis periphery toward the sperm duct. The sperm duct results from connection of efferent ducts at the center of the testis and this applied with Alka'abi (1996). Testis of $O$. niloticus was composed of coiled tubular branching seminiferous tubules that were delimited by a basal lamina, and contained both germ and Sertoli cells. Somatic cells, such as Leydig cells and blood vessels, were located between the tubules. Seminiferous tubules had a central lumen surrounded by the germinal epithelium. This was organized in spermatocysts, where spermatogenesis occurred. The walls of spermatocysts were formed by cytoplasmic processes of Sertoli cells. Each cyst contained germ cells at the same stage of development, these are similar to the observations of Schulz, R.W.; Menting, S.; Bogerd, J.; Franca, L.R.; Vilela, D.A. and Godinho, H.P. (2005). The testicular organization of $O$. niloticus corresponds to the unrestricted (cystic) type, where spermatogenesis is completed within spermatocysts and leads to synchronous development of germ cells. These results agreed with Mattei, X.; Siau, Y.; Thiaw, O.T. and Thiam, D. (1993) and Hamdoon and Zayed (1998). Spermatogenesis occured in a series of a process, 
which involves; a) proliferation of spermatogonia through repeated mitotic divisions; b) growth of spermatogonia to form primary spermatocytes; c) then undergo reduction division to form secondary spermatocytes; d) the division of secondary spermatocytes produces spermatids; and e) the metamorphosis occured to form the motile spermatozoa. Mature spermatocysts open to release cohorts of sperm into a central lumen, which lead to a contagious system of efferent ducts. Similar findings were reported by Amiri, et al. (1996) who studied the testicular development and serum sex steroid profiles during the annual sexual cycle of the male sturgeon hybrid; Redding and Patino (1993) who studied the reproductive physiology of fishes and Gomes and Araujo (2004) who studied the reproductive biology of two marine catfishes. The present study revealed significantly increase in number of Sertoli cells per spermatocyst during the breeding season, such observation is similar to that mentioned by Sculz, et al. (2005), however, evidence for proliferation such an increase mitotic divisions in Sertoli cells was not observed. In addition, it can be suggested that, during the non-breeding season, the Sertoli cells regress or severally reduced in size that could not be visible by the light microscopy, however during the spawning or breeding season, these cells flourished up and increased in size that made it microscopically visible. Moreover, further investigations are required to identify the possible reasons of increased number of Sertoli cells per spermatocyst during breeding season in the Nile Tilapia.In the same respect, Hibiya (1982) believed that Sertoli cells play a role in supplying of nutrients to the germ cells, while Redding and Patino (1993) mentioned that these cells are responsible for the physical support and regulation of spermatogenesis. On the other hand, Cinquetti and Dramis (2003) stated that Sertoli cells were involved in phagocytosis of degenerating, residual sperm cells and in spermatogonial proliferation. In addition, these cells considered to be the main constituent of the blood testicular barrier, which developes usually before or after meiosis and it maintains features of intense protein synthesis throughout the whole spawning season. In agreement with Redding and Patino (1993), Leydig (interstitial, interlobular) cells are interspersed in the connective tissue surrounding the seminiferous tubules; their primary function is to produce sex steroids (testosterone) needed for gametogenesis and expression of secondary sex characteristics. From observations of the present study, it was found that during spermiogenesis, the spermatids mature and develop to become spermatozoa, spermatozoa is collected in the efferent tubules, from 
which they are expelled during spermiation (sperm release). The efferent ducts of the testes join to form spermatic ducts. The paired spermatic ducts coalesce distally to form the sperm duct which emptied into urogenital. These findings in agreement with the results obtained by Amiri, et al. (1996).

\section{REFERENCES}

Alka'abi, N.A.O. (1996): Histological and histochemical comparative studies on gonads of Grouper fish in Arabian Gulf and Tilapia fish in aquacultures. Ph.D. Department of Zoology, Collage of Science for Girls. Dammam- KSA.

Amiri, B.M.; Maebayashi, M.; Adachi, S. and Yamauchi, K. (1996): Testicular development and serum sex steroid profiles during the annual sexual cycle of the male sturgeon hybrid, the bester. J. Fish Biology., 48: 1039-1050.

Arockiaraj, A.J.; Haniffa, M.A.; Seetharaman, S. and Singh, S. (2004): Cyclic changes in gonadal maturation and histological observations of threatened freshwater catfish "Narikeliru" Mystus montanus (Jerdon, 1849). J. Acta Icthyologica et Piscatoria., 34(2): 253-266.

Beamish, C.A.; Booth, A.J. and Deacon, N. (2005): Age, growth an reproduction of largemouth bass, Micropterus salmoides, in lak Manyame, Zimbabwe. J. African Zoology., 40(1): 63-69.

Bond, C.E. (1979): Biology of fishes. By Saunders College Publishing.

Caputo, V.; Mesa, M.L.; Candi, G. and Cerioni, P.N. (2003): The reproductive biology of the crystal goby with a comparison to that of the transparent goby. J. Fish Biology., 62: 375-385.

Cinquetti, R. and Dramis, L. (2003): Histological, histochemical, enzyme histochemical and ultrastructural investigations of the testis of Padogobius martensi between annual breeding seasons. J. Fish Biology., 63: 1402-1428.

Gomes, I.D. and Araujo, F.G. (2004): Reproductive biology of two marine catfishes (Siluriformes, Ariidae) in the Sepetiba Bay, Brazil. J. Revista de Biologia Tropical., 52 (1).

Grossmon, G. (1937): A modification of Mallory's connective tissue stain with discussion of the principle involved. Anat. Rec., 69: 33-38. Cited by Bancroft, J.D. and Steven, A. (1996): Theory and practice of histological techniques. $4^{\text {th }}$ ed. Churchill Livingstone. New York. Edinburgh. London. Madrid. Melbourne. San Francisco. Tokyo. 
Hamdoon, N.T. and Zayed, A.E. (1998): Feminization of Nile Tilapia Oreochromis niloticus by oral administration of sex reversal hormone "Diethylstilbestrole". J. Asssuit Vet.Med., 39 (78): 117-129.

Harris, H.F. (1900): On the rapid conversion of haematoxylin into haematin in staining reactions. J. Applied Microscopic Laboratory Methods., 3-777. Cited by Bancroft, J.D. and Steven, A. (1996).

Hatikakoty, G. and Biswas, S.P. (2004): Studies certain aspects of the reproductive biology of mouth-brooding tilapia, Oreochromis mossambicus (Peters) from Assam, India. The Six International Symposium on Tilapia in Aquaculture., 112-126.

Hibiya, T. (1982): An atlas of fish histology- Normal and pathological features. Kondansha Ltd. Tokyo. Gustav Fischer Verlag. Stuttgart. New York.

Mattei, X.; Siau, Y.; Thiaw, O.T. and Thiam, D. (1993): Peculiarities in the organization of testis of Ophidion sp. (Pisces Teleostei). Evidence for two types of spermatogenesis in teleost fish. J. Fish Biology., 43: 931-937.

McManus, J.F.A. (1946): Histological demonstration of mucin after periodic acid. Nature. London. 158-202. Cited by Bancroft, J.D. and Steven, A. (1996).

Peterson, M.S.; Slack, W.T.; Brown-Peterson, N.J. and McDonald, J.L. (2004): Reproduction in nonnative environments: Establishment of Nile tilapia, Oreochromis niloticus, in Coastal Mississippi Watersheds. Copeia., 4: 842-849.

Redding, J.M. and Patino, R. (1993): Reproductive physiology. Chapter 16 In D.H. Evans, Ed. The Physiology of Fishes, CRC Press.

Roberts, R.J. (1978): Fish pathology. Bailliere Tindall, London.

Schulz, R.W.; Menting, S.; Bogerd, J.; Franca, L.R.; Vilela, D.A. and Godinho, H.P. (2005): Sertoli cell proliferation in the adult testis-evidence from tow fish species belonging to different orders. J. Biology of Reproduction., 73(5): 891-898.

Trewawas, E. (1982): Tilapias: taxonomy and speciation, In R.S.V. Pullin and R.H Low e-Mc Conell (eds.) The Biology and Culture of Tilapia. ICLARM Conf. Proc., 7: 3-13.

Verhoeff, F.H. (1908): Some new staning methods of wide applicability. Including a rapid differential stain for elastic tissue. J. Med. Assoc., 50,876. Cited by Bancroft, J.D. and Steven, A. (1996). 